\title{
pneumonia
}

Review

\section{Viral pneumonia in adults and older children in sub-Saharan Africa - epidemiology, aetiology, diagnosis and management}

\author{
Antonia $\mathrm{Ho}^{\mathrm{a}, \mathrm{b}}$ \\ ${ }^{a}$ Malawi Liverpool Wellcome Trust Clinical Research Programme, Blantyre, Malawi; ' Institute of Infection and Global Health, University of Liverpool, \\ Liverpool, United Kingdom
}

Corresponding author: Antonia Ho, Malawi Liverpool Wellcome Trust Clinical Research Programme, Chichiri, Blantyre 3, Malawi. Phone: +265 996151231. Email: toniho@doctors.org.uk

\begin{abstract}
Author contributions: AH met authorship criteria. AH wrote the first draft of the manuscript and subsequent revisions, and critically reviewed the manuscript for important intellectual content.
\end{abstract}

Received Feb 26, 2014; Accepted Jun 27, 2014; Published Aug 27, 2014

Citation: Ho A. Viral pneumonia in adults and older children in sub-Saharan Africa - epidemiology, aetiology, diagnosis and management. pneumonia 2014;5:18-29

\begin{abstract}
Community-acquired pneumonia causes substantial morbidity and mortality in sub-Saharan Africa with an estimated 131 million new cases each year. Viruses - such as influenza virus, respiratory syncytial virus and parainfluenza virus - are now recognised as important causes of respiratory disease in older children and adults in the developed world following the emergence of sensitive molecular diagnostic tests, recent severe viral epidemics, and the discovery of novel viruses. Few studies have comprehensively evaluated the viral aetiology of adult pneumonia in Africa, but it is likely to differ from Western settings due to varying seasonality and the high proportion of patients with immunosuppression and co-morbidities. Emerging data suggest a high prevalence of viral pathogens, as well as multiple viral and viral/bacterial infections in African adults with pneumonia. However, the interpretation of positive results from highly sensitive polymerase chain reaction tests can be challenging. Therapeutic and preventative options against viral respiratory infections are currently limited in the African setting. This review summarises the current state of the epidemiology, aetiology, diagnosis and management of viral pneumonia in sub-Saharan Africa.
\end{abstract}

Keywords: viral pneumonia, viral respiratory tract infections, adult, older children, Africa, sub-Saharan Africa 


\section{Introduction}

Community-acquired pneumonia (CAP) is a leading cause of morbidity and mortality in all age groups worldwide (1). The African continent carries a substantial burden around $30 \%$ of the estimated 430 million episodes of lower respiratory tract infections (LRTI) each year (1). Bacteria, for example, Streptococcus pneumoniae, are the principal causative agents in adult pneumonia $(2,3)$. However, the availability of sensitive molecular tests has resulted in the increasing recognition of viruses as major contributors (4, 5). Moreover, the emergence of avian influenza $A(H 5 N 1)$ virus and 2009 pandemic influenza $A(H 1 N 1)$ virus, along with the accelerated discovery of other novel respiratory viruses (e.g., human metapneumovirus [hMPV], bocavirus, coronaviruses NL63 and HKU1, Middle East Respiratory Syndrome [MERS]), against a backdrop of a growing population of immunocompromised individuals has catalysed research attention on severe viral respiratory infections in adults.

Available data on the contribution of viruses to adult CAP comes mainly from studies in developed settings (4, $5)$. Viral causes of pneumonia in African adults are less well characterised, largely due to the lack of access to appropriate diagnostics. The epidemiology, aetiological agents, seasonality, and age distribution of patients are likely to differ substantially from the developed setting for a myriad of reasons. Firstly, respiratory viruses typically follow seasonal patterns. In contrast to the distinct winter epidemics as seen in temperate regions, available influenza data indicate year round transmission in most African regions (6). Secondly, high prevalence of human immunodeficiency virus (HIV) infection and other comorbidities (e.g., tuberculosis [TB]) are likely to impact on the epidemiology and microbial aetiology of adult viral respiratory presentations (7). Several pneumonia aetiology studies in Africa have described a preponderance of younger adults (aged 15-45 years) $(8,9)$. Additionally, LRTI with herpes viruses, such as cytomegalovirus (CMV), herpes simplex virus (HSV) and varicella zoster virus (VZV), are common in adults in Western settings (10) and children in sub-Saharan Africa (11) with advanced immunosuppression. Moreover, immunocompromised patients may have more severe presentations. Emerging data from South Africa describes higher risk of death in HIV-infected adults with influenza infection (12). Lastly, many developed settings recommend targeted (13) or universal (14) seasonal influenza vaccination, but few African countries have national influenza vaccination programmes (15).

This paper reviews the current knowledge on the epidemiology and aetiology of viral pneumonia in adults and older children in sub-Saharan Africa, and evaluates the available options for diagnosis, prevention and management, and viral respiratory pathogens in this resource-poor setting.

\section{Definitions and search strategy}

The absence of a standardised case definition has been a longstanding problem of pneumonia aetiology studies. Most studies undertaken in developed settings have focused on radiologically-confirmed pneumonia (i.e. the presence of new infiltrates on chest radiograph [x-ray] with clinical symptoms suggestive of LRTI) (16-25). Given the inconsistent availability of chest radiographs in African health settings (26), a broader definition of pneumonia was used to include clinical evidence of LRTI with or without confirmed chest radiograph changes.

A literature search of original research articles using the PubMed database from inception through 31 May 2014 was conducted. The following PubMed search strategy was used: ("acute respiratory infection"[All Fields] OR "acute lower respiratory tract infection" [All Fields] OR "severe acute respiratory infection"[All Fields] OR "pneumonia"[All Fields] OR "pneumonia”[ MeSH Terms]) AND ("Africa" [MeSH Terms] OR "Africa” [All fields]).

The following inclusion criteria were used: (i) study population of patients aged $>5$ years of age; (ii) study population of patients with radiologically-confirmed pneumonia or clinical LRTI; (iii) study population of patients that have been hospitalised; and (iv) study in any language. Since the purpose of this review was to describe the viral causative pathogens of African adults and older children presenting with pneumonia, studies that only examined for influenza or bacterial pathogens were excluded (Figure 1).

\section{Viral epidemiology and aetiology in sub-Saharan Africa}

Few studies have comprehensively examined the microbial aetiology of pneumonia in Africa; even fewer have included viral diagnostics. A growing number of acute respiratory infection (ARI) surveillance studies in sub-Saharan Africa, with particular interest in influenza virus (27-41) and respiratory syncytial virus (RSV) (42), have been published since the emergence of pandemic influenza $A(H 1 N 1)$ virus in 2009, reflecting the rapid expansion in surveillance capacity in the region (43). However, most were excluded from this review as they focused on a single virus and did not fulfill the inclusion criteria of patients hospitalised with LRTI. We identified 5 studies in African individuals aged 5 years and over with hospitalised LRTI in whom viral aetiology was evaluated $(8,39,41,44,45)$ (Tables 1 and 2). There was substantial heterogeneity in the study populations, clinical case definitions of "pneumonia" (in terms of types and duration of clinical symptoms, and requirement for chest radiograph changes), and clinical specimens obtained for viral testing (Table 1). Three of the 5 studies did not include whole years of observation $(44,46)$, which may over- or underestimate the burden of 


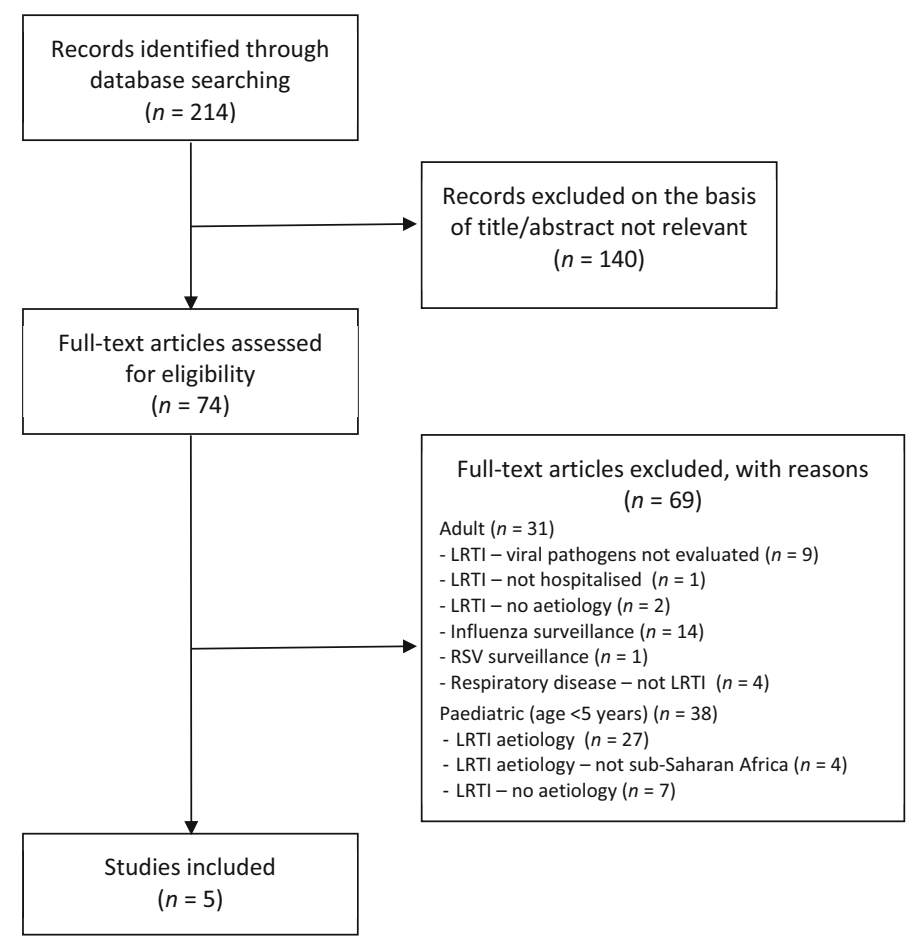

LRTI, lower respiratory tract infection; RSV, respiratory syncytial virus

Figure 1 Flow chart of identification and selection of studies that have evaluated viral aetiology of pneumonia in adults and older children in sub-Saharan Africa

viral infections depending on the study period included. Two studies conducted prior to 2000 used viral culture and serology $(8,44)$. The others utilised polymerase chain reaction (PCR)-based methods. All studies tested for influenza A and B viruses, adenovirus and RSV, and most also examined for parainfluenza virus (PIV) and enteroviruses. More recent studies have encompassed testing for rhinovirus $(39,41,45), \operatorname{hMPV}(39,41,45)$, coronaviruses (45) and bocavirus (45). Of note, none tested for CMV. HIV prevalence was high (49-94\%) among the 3 studies that reported serostatus $(8,39,45)$.

The percentage of patients with at least one viral pathogen ranged from $5.7 \%$ to $58 \%$ (Table 2 ), which is comparable to the $11-56 \%$ reported in contemporary studies in developed settings $(16-21,47)$. The earliest study, conducted in South African black miners hospitalised with acute respiratory disease (definition not stated), reported detection of a respiratory virus in $47 \%$ of cases using viral culture and serology (44). In particular, a very high proportion of influenza $A(28 \%)$ virus was found, even though whole years of observations were included. The authors attributed the prolonged influenza epidemic in the miners to the close working conditions that facilitated transmission and high staff turnover which maintained a large pool of susceptible individuals. In contrast, a prospective hospital-based study by Scott et al. (8) only identified a viral pathogen in $5.7 \%$ of adults with hospitalised pneumonia in Kenya. However, serology was the sole viral diagnostic method used to test for a small number of viruses.

A prospective observational study in pneumonia patients admitted to a high dependency unit (HDU) of a tertiary referral hospital in Malawi found a viral pathogen in 11 of 51 (22\%) patients (45) - 3 had a final diagnosis of viral pneumonitis, whereas the rest had an alternative diagnosis (pulmonary Kaposi's sarcoma) or pathogen (e.g., Mycobacterium tuberculosis) that was considered the primary cause for severe respiratory presentation. The study was limited to those who could tolerate a bronchoscopy (with resultant exclusion of $39 \%$ of eligible patients), which likely introduced selection bias. Moreover, two-thirds of patients had symptom duration of greater than 3 weeks, which may have accounted for the high proportion of Pneumocystis jiroveci pneumonia (PCP) (27\%) and M. tuberculosis (22\%).

The latest studies are derived from epidemiological surveillance in Kenya (39) and South Africa (41). Both studies reported high rates of viral infection - in particular, high prevalence of rhinovirus, enterovirus, influenza virus and adenovirus were found (Table 2). Feikin et al. (39) also enrolled asymptomatic hospital controls, hence the authors were able to infer the absence of association with clinical illness in a number of commonly identified viruses (namely, rhinovirus, enterovirus and adenovirus). 
Table 1: Characteristics of studies on viral aetiology in hospitalised adults and older children with pneumonia or clinical lower respiratory tract infection in sub-Saharan Africa.

\begin{tabular}{|c|c|c|c|c|c|c|c|}
\hline $\begin{array}{l}\text { Study, year } \\
\text { [ ] Reference }\end{array}$ & Country & $\begin{array}{l}\text { Study } \\
\text { period }\end{array}$ & Setting & $\begin{array}{l}\text { Study } \\
\text { population }\end{array}$ & "Pneumonia" definition & Specimen & Viral diagnostic test \\
\hline $\begin{array}{l}\text { Joosting et al., } \\
1979 \text { [44] }\end{array}$ & $\begin{array}{l}\text { South } \\
\text { Africa }\end{array}$ & $\begin{array}{l}\text { May 1966- } \\
\text { Apr } 1972\end{array}$ & $\begin{array}{l}\text { Hospital-based } \\
\text { observational } \\
\text { study }\end{array}$ & $\begin{array}{l}\text { Black } \\
\text { miners }\end{array}$ & $\begin{array}{l}\text { Acute respiratory disease } \\
\text { (definition not stated) }\end{array}$ & $\begin{array}{l}\text { Throat } \\
\text { swabs \& } \\
\text { serum }\end{array}$ & $\begin{array}{l}\text { Viral culture \& } \\
\text { serology (HAl or } \\
\text { complement fixation) }\end{array}$ \\
\hline $\begin{array}{l}\text { Scott et al., } \\
2000[8]\end{array}$ & Kenya & $\begin{array}{l}\text { Mar 1994- } \\
\text { May } 1996\end{array}$ & $\begin{array}{l}\text { Hospital-based } \\
\text { observational } \\
\text { study }\end{array}$ & $>15$ years & $\begin{array}{l}\text { Pneumonia ( }>2 \text { symptoms of } \\
\text { fever, cough, sputum, chest } \\
\text { pain, SOB, or haemoptysis; } \\
\text { symptoms <14 days; } \\
\text { consolidation on CXR) }\end{array}$ & Serum & Complement fixation \\
\hline $\begin{array}{l}\text { Hartung et al., } \\
2011 \text { [45] }\end{array}$ & Malawi & $\begin{array}{l}\text { Feb 2006- } \\
\text { Sept } 2006\end{array}$ & $\begin{array}{l}\text { Hospital-based } \\
\text { observational } \\
\text { study }\end{array}$ & $>18$ years & $\begin{array}{l}\text { Pneumonia (>1 symptom of } \\
\text { cough, sputum, chest pain, SOB, } \\
\text { chest pain or haemoptysis; CXR } \\
\text { changes) + admission to HDU }\end{array}$ & BAL fluid & rRT-PCR \\
\hline $\begin{array}{l}\text { Feikin et al., } \\
2012 \text { [39] }\end{array}$ & Kenya & $\begin{array}{l}\text { Mar 2007- } \\
\text { Feb } 2010\end{array}$ & $\begin{array}{l}\text { Population-based } \\
\text { surveillance }\end{array}$ & $>5$ years & $\begin{array}{l}\text { ARI (cough or difficulty } \\
\text { breathing or chest pain and } \\
\text { temperature }>38.0^{\circ} \mathrm{C} \text { or } \\
\text { oxygen saturation }<90 \% \text { or } \\
\text { hospitalisation) }\end{array}$ & $\begin{array}{l}\text { NP \& OP } \\
\text { swabs }\end{array}$ & rRT-PCR \\
\hline $\begin{array}{l}\text { Pretorius et al., } \\
2012 \text { [41] }\end{array}$ & $\begin{array}{l}\text { South } \\
\text { Africa }\end{array}$ & $\begin{array}{l}\text { Feb 2009- } \\
\text { Dec } 2010\end{array}$ & $\begin{array}{l}\text { Hospital-based } \\
\text { surveillance } \\
\text { (6 hospitals) }\end{array}$ & $>5$ years & $\begin{array}{l}\text { SARI (fever; cough or sore } \\
\text { throat; shortness of breath or } \\
\text { difficulty breathing; symptoms } \\
<7 \text { days) }\end{array}$ & $\begin{array}{l}\text { NP \& OP } \\
\text { swabs }\end{array}$ & rRT-PCR \\
\hline
\end{tabular}

HAI, haemaglutination inhibition assay; SOB, shortness of breath; CXR, chest radiograph (x-ray); HDU, high dependency unit; BAL, bronchoalveolar lavage; rRT-PCR, real-time reverse transcriptase polymerase chain reaction; ARI, acute respiratory infection; NP, nasopharyngeal; OP, oropharyngeal; SARI, severe acute respiratory infection.

Conversely, influenza A virus and RSV were significantly associated with hospitalised ARI. Pretorius et al. (41), the largest study to date with greater than 4,000 patients, was able to report age-stratified prevalence of detected viruses. They demonstrated the highest prevalence of viruses in hospitalised severe acute respiratory infection (SARI) patients aged 5-24 years (51\%), compared to older age groups ( $25-44$ years, $34 \%$; $45-64$ years, $29 \%$; $>65$ years, $24 \%)$.

Outcome data were sparse among the included studies mortality of $10 \%$ and $22 \%$ were reported by Scott et al. (8) and Hartung et al. (45), respectively; Feikin et al. (39) found a case fatality ratio of $6 \%$ in persons aged 5 years and over with hospitalised ARI. However, none of the studies reported clinical outcome according to underlying viral or bacterial aetiology. Moreover, there were limited data on high-risk groups such as HIV-infected individuals, adults with underlying co-morbidities, and the elderly. Feikin et al. (39) described higher incidence rates of all pathogens in HIV-infected compared to HIV-uninfected adults, but this analysis included both inpatients and outpatients. Pretorius et al. (41) did not find higher prevalence of virus in adults aged 65 years and over compared to younger age groups. Although beyond the scope of this review, young children are also an important risk group. The aetiology and risk factors for hospitalised pneumonia in this group are being addressed by the Pneumonia Etiology Research for Child Health (PERCH) project, a multi-site case control study in 7 countries, 5 of which are in sub-Saharan Africa (48).

\subsection{Multiple pathogen infection}

As a result of an expanding armamentarium of diagnostic tests, viral-viral and viral-bacterial co-infections are increasingly identified. Several studies in well-resourced settings have found more severe disease and poorer outcomes in patients with polymicrobial infections (16, $17,19,22)$. However, the clinical interpretation of mixed infections is not straightforward since detection of multiple pathogens could reflect three possible scenarios: i) all detected organisms have contributed to pathogenesis; ii) $>1$ detected organism is an innocent bystander; iii) one organism is the predisposing factor (e.g., by damaging the respiratory epithelium) to cause pneumonia by the second organism.

Influenza virus and S. pneumoniae is the most studied co-infection combination; their synergistic interaction is well described $(49,50)$. In the African setting, the pneumococcal conjugate vaccine (PCV) has been shown to prevent $31 \%$ of viral pneumonia in South African children (51), providing epidemiological evidence of the importance of pneumococcal co-infection in viral pneumonia. More 
Table 2: Results of studies on viral aetiology in hospitalised adults and older children with acute lower respiratory tract infection or pneumonia in sub-Saharan Africa

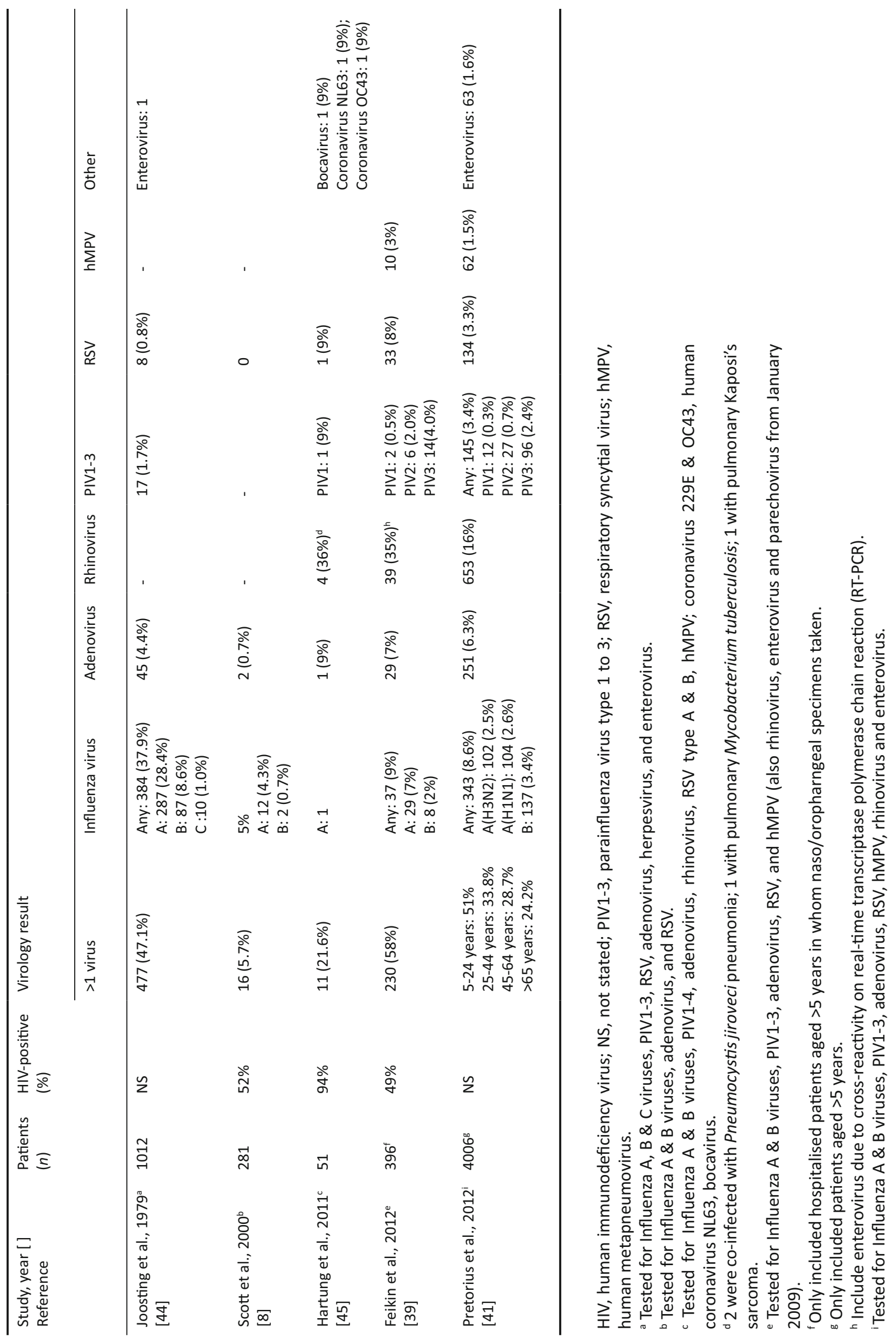


recently, a hospital-based surveillance study in South Africa described elevated blood pneumococcal load (as a marker for invasive pneumococcal pneumonia) in patients with influenza virus co-infection (52).

All but one of the included African studies described mixed infection. Scott et al. (8) reported bacterial pneumonia in 8 of 12 cases with influenza. Viral co-infections (rhinovirus [n = 3]; coronaviruses OC43 and NL63; RSV and PIV type 1 [PIV1]) with bacteria/fungus (including Staphylocccus aureus, Klebsiella pneumoniae, $P$. jiroveci and $M$. tuberculosis) were demonstrated in 7 of 51 (14\%) cases of the Malawian HDU cohort (45). The recent ARI surveillance study in Kenya demonstrated mixed viral and bacterial infections in $29 \%$ of patients $(39,41)$. Co-infections were more common in HIV-positive than HIV-negative patients, and influenza virus was less likely to be co-infected with other viruses, compared with other viral pathogens (39). Pretorius et al. (41) reported viral co-infections in $17 \%$ of hospitalised pneumonia patients (this included children $<5$ years), but were unable to correlate co-infection with clinical outcome due to the low number of specific coinfection combinations. Among co-infected patients in the Kenyan and South African studies, adenovirus, rhinovirus and RSV were the most frequently detected viruses. Feikin et al. (39) found a similar prevalence of rhinovirus and adenovirus in cases and controls, implying that their identification in ARI cases may not be clinically significant. Nonetheless, the contribution of these commonly identified viruses to disease severity is often unclear from available literature.

The role of rhinovirus in pneumonia is contentious. On one hand, asymptomatic carriage is well described in immunocompetent (53) and immunocompromised patients (54). Conversely, viral shedding beyond 2 weeks of acute illness is rare, suggesting an association with clinical disease $(55,56)$. Furthermore, rhinovirus has been associated with hospitalised LRTI in Thai adults (57), and has also been the suspected causative organism in several outbreaks of severe respiratory diseases in nursing homes in the United States $(58,59)$.

In contrast, asymptomatic carriage of adenovirus (60) and RSV (61) are uncommon. Hence their presence is usually pathogenic. Adenovirus has been implicated as a cause of pneumonia in South African and Chinese adults, although neither study had a control group $(44,62)$.

\subsection{Limitations of current studies}

Given the wide variation in time period, study population, pneumonia definition, clinical specimens, diagnostic methods, and number of pathogens tested, it is difficult to make any firm conclusions from the handful of studies available beyond that viral pathogens are prevalent in older children and adults in sub-Saharan Africa presenting with severe ARI. Mixed infections are common. With the exception of Feikin et al. [39], the lack of control group is a major limitation, as the background prevalence of asymptomatic viral infections is undefined (see section 4.2 for the role of healthy controls).

\section{Diagnosis of viral pneumonia}

\subsection{Evolution of viral diagnosis in acute respiratory infections}

Conventional diagnostic methods, such as, viral culture and immunofluorescence microscopy of respiratory specimens or serological testing of acute and convalescent serum samples, have limited clinical applicability due to lengthy processing time and poor sensitivity (63). Nucleic acid amplification tests (NATs), such as PCRbased methods, have greatly enhanced detection of respiratory viral pathogens. They demonstrate superior sensitivity compared to conventional methods (64), are able to detect viruses that are difficult to culture (e.g., hMPV, coronaviruses NL63 and HKU1, and rhinovirus), can rapidly characterise new viral pathogens (65), and can yield results in a clinically relevant time frame. Moreover, multiplex platforms enable simultaneous detection of a large number of viral pathogens from a single specimen, thus facilitating diagnostic efficiency and cost-effectiveness (66). Studies in well-resourced settings have demonstrated higher microbial yield when conventional diagnostic techniques are augmented by NATs (16-19), which now form the backbone of respiratory viral testing in both well resourced and surveillances sites in low-income settings.

\subsection{Challenges in interpretation of viral diagnostic results}

Lower respiratory tract samples (e.g., induced sputum, bronchoalveolar lavage or transthoracic needle aspiration) provide the most sensitive specimens for determining the likely cause of pneumonia since they are taken from the site of infection $(67,68)$. However, they are difficult to obtain and unfeasible in most African settings. Viral diagnosis therefore mostly relies on upper respiratory specimens, but the high sensitivity of molecular tests complicates the interpretation of a positive result (69). Viruses identified from nasopharyngeal specimens can be the underlying cause of LRTI, but may also represent contamination, colonisation, post-infectious shedding, or the predisposing agent to subsequent bacterial superinfection. Thus, attributing causality to every positive PCR result may overestimate the contribution of respiratory viruses, particularly if diagnostic tests for other pathogens, such as blood culture, have comparatively low sensitivity.

Molecular results should be interpreted in the context of the patient's clinical presentation and known epidemiology of the detected viral pathogens. Additionally, viral load quantification $(70,71)$ or ascertainment of background prevalence of asymptomatic nasopharyngeal viral infection in a control group $(39,48)$ could further clarify 
the pathogenic roles of detected viruses. A study design analogous to the PERCH study, whereby multiple upper and lower respiratory specimens are obtained from pneumonia cases and community controls, will allow the strength of association between a positive result and pneumonia to be established, in addition to comparison of concordance of microbial results between upper and lower respiratory specimens from the same patient (48).

\subsection{Expansion of diagnostic capacity in Africa}

Over the past decade, the emergence of the highly pathogenic avian influenza $A(H 5 N 1)$ virus and pandemic influenza $A(H 1 N 1)$ virus highlighted the need to strengthen capacity for ARI surveillance in sub-Saharan Africa (43). With financial and technical support from national and international institutions such as the World Health Organisation (WHO), Centers for Disease Control and Prevention (CDC), Institut Pasteur and the National Institute for Communicable Diseases in South Africa, a growing number of countries in the region have acquired PCR diagnostic capabilities $(35,43)$. At least 24 African countries now contribute specimens to WHO influenza surveillance (72). Nevertheless, the operation of a molecular diagnosis laboratory in resource-poor settings is associated with major challenges - the requirements for reliable power source; access to reagents, equipment, trained technicians and skilled maintenance; in addition to robust sample transfer and storage systems and stringent quality control, represent significant barriers to widespread implementation of PCR testing in Africa (73). For the foreseeable future, PCR diagnostics are likely to be confined to research settings and institutionally-supported surveillance programmes. However, demonstration of substantial burden of respiratory viruses in ARI may gather momentum for global health partners to expand respiratory viral diagnostic capability to other sub-Saharan countries, and convince governments of individual countries to invest in infrastructure to support PCR diagnosis as a step towards sustainability (35).

\section{Management and prevention}

\subsection{Management}

Antivirals against respiratory viruses are prohibitively expensive and largely unavailable in sub-Saharan Africa. Despite the likely prevalence of CMV pneumonitis, there are no published reports on ganciclovir use in adult CMV disease on the continent (11). With the exception of aciclovir for the treatment of HSV and VZV (74), antiinfluenza agents, namely neuraminidase inhibitors (NI) (oseltamivir and zanamavir) and $\mathrm{M} 2$ inhibitors (amantadine and rimantadine), are the only antivirals available in a small number of African settings (15). Moreover, due to widespread resistance against seasonal influenza $A(H 3 N 2)$ virus and pandemic influenza $A(H 1 N 1)$ virus in recent years (75), M2 inhibitors are no longer recommended for the treatment or prophylaxis of influenza A virus (76).

NIs have been shown to be $68-92 \%$ effective in preventing influenza in healthy adults and children in developed settings (77). In a recent Cochrane review, oseltamivir was associated with a shortening of illness duration by 0.7 days (78). Due to the lack of diagnostic definitions, it is unclear whether NIs reduce the risk of influenza complications such as pneumonia (78), though they had no effect on rates of hospitalisation (78). Data on the impact of NIs on hospitalised or immunosuppressed patients with influenza pneumonia are scarce. Current evidence, largely derived from retrospective studies, suggests that oseltamivir accelerates viral clearance (79), reduces length of hospital stay (80) as well as lowers mortality in patients hospitalised with influenza $(81,82)$. Specifically in HIV-infected individuals, several studies have suggested that oseltamivir reduces severity of illness (83), but no prospective evaluation of the efficacy of NIs in HIV-infected individuals or in African settings has been undertaken.

NIs are most effective if administered within 48 hours of symptom onset (84). The lack of viral testing in 'realtime', broad differential diagnosis of acute respiratory presentations in high HIV prevalence settings, in addition to high cost and lack of availability, are barriers to the widespread and effective use of NIs in the region at present.

\subsection{Prevention}

With a shortage of therapeutic options, prevention and control of viral pneumonia should be focused on infection control and vaccines. Core infection control measures, such as cohorting and isolation, are impractical in many resource-poor settings. However, physical interventions such as handwashing, use of masks, gloves and aprons may be feasibly implemented to minimise risk of nosocomial spread $(85,86)$.

Vaccine options are limited for the prevention of respiratory viral infections - the only approved vaccine is against seasonal influenza. In well-resourced settings, annual influenza vaccination with trivalent or quadrivalent inactivated vaccines (TIV/QIV) or an intranasal live attenuated vaccine (LAV) has an established role in preventing influenza infection and its complications $(13,14)$. LAV is contraindicated in immunosuppressed or pregnant patients, thus unsuitable for widespread use in sub-Saharan Africa where HIV prevalence is high. Only 2 studies have evaluated efficacy or effectiveness of TIV in Africa, both from South Africa. Age-adjusted vaccine effectiveness of TIV, estimated from a surveillance programme on patients with influenza-like illness (ILI), ranged from $-14 \%(95 \% \mathrm{Cl}-100 \%$ to $35 \%)$ to $67 \%(95 \% \mathrm{Cl}$ $12 \%-90 \%)$ between 2005 and 2009, though low vaccine 
coverage (approximately $4 \%$ among ILI cases) may have reduced the power to estimate vaccine effectiveness (87). A randomised double blind placebo-controlled trial of TIV in HIV-infected adults demonstrated vaccine efficacy of $75.5 \%$ (95\% Cl 9.2\%-95.6\%) (88), which is comparable to that in developed settings (89). However, excluded patients with underlying co-morbidities and advanced immunosuppression (antiretroviral therapy naïve with CD4 $<100$ cells $/ \mu \mathrm{L}$ ). Evaluation of TIV or QIV efficacy in this high-risk group is required.

A recent CDC survey reported availability of seasonal influenza vaccine in 14 of 31 (45\%) African countries (15). However, only 2 sub-Saharan African countries (Côte d'Ivoire and Mauritius) reported to have a national public policy for influenza vaccination. Even if annual seasonal influenza vaccination became national policy, its implementation will be logistically challenging. There is currently no indigenous vaccine production in the region (72). Additionally, the vaccine donation initiative that provided 2009 pandemic influenza (H1N1) virus vaccines also highlighted problems in vaccine procurement, distribution and uptake in the region (72).

A number of vaccines against other important viral pathogens such as RSV (90) and PIV type 3 (PIV3) (91) are under development. Furthermore, given the protective effect of pneumococcal vaccination on viral pneumonia in children (51), the current PCV roll-out in children in a number of African countries may result in an indirect benefit on adult viral pneumonia (92).

\section{Conclusion}

Increasing deployment of sensitive molecular diagnostic assays has improved our ability to characterise the contribution of viruses to adult pneumonia. Viruses commonly identified in CAP in the Western setting - namely rhinovirus, influenza virus, RSV and PIV - are prevalent in adults and older children presenting with hospitalised pneumonia in sub-Saharan Africa. Novel viruses such as hMPV and human bocavirus are increasingly identified. This review highlights the scarcity of literature on viral aetiology in adult CAP, especially in at-risk groups such as HIV-infected individuals, though data are beginning to emerge from SARI surveillance and prospective observational studies.

Vaccine and treatment options for viral respiratory pathogens remain limited and out of reach for most of subSaharan Africa, and evidence for their use in this setting is lacking. Nonetheless, ongoing epidemiological surveillance is important to evaluate temporal variations of circulating viruses and anticipate future outbreaks and pandemics. Better characterisation of the burden and spectrum of viruses that contribute to adult CAP in the region will also enable more informed interpretation of positive molecular results, aid decisions on important pathogens to include in respiratory disease surveillance programmes, as well as the most pathogenic viruses to target for vaccine and antiviral development. Furthermore, establishing a substantial burden of virus-associated severe respiratory infection (in particular influenza) may persuade local policy makers to consider targeted immunisation programmes - annual influenza vaccination in at-risk adults and PCV in children could potentially prevent a substantial proportion of viral pneumonia in adults.

Funding: This work was supported by the Wellcome Trust [Grant 097464]. The funder had no role in study design, collection and analysis of data, decision to publish, or writing of the manuscript.

Competing interests: $\mathrm{AH}$ declares no competing interests.

Provenance and peer review: Commissioned; no funding has been requested or received by the author for the preparation of the manuscript; externally peer reviewed.

Copyright: This is an open-access article distributed under the terms of the Creative Commons Attribution License, which permits unrestricted use, distribution, and reproduction in any medium, provided the original author and source are credited.

\section{References}

1. World Health Organization. The global burden of disease: 2004 update. Switzerland: World Health Organization, 2008

2. Welte T, Torres A, Nathwani D. Clinical and economic burden of community-acquired pneumonia among adults in Europe. Thorax. 2012;67(1):71-9. http://dx.doi. org/10.1136/thx.2009.129502

3. Peto L, Nadjm B, Horby P, Ngan TT, van Doorn R, Kinh NV, et al. The bacterial aetiology of adult community-acquired pneumonia in Asia: a systematic review. Transactions of the Royal Society of Tropical Medicine and Hygiene. 2014;108(6):326-37. http://dx.doi.org/10.1093/trstmh/ tru058

4. Ruuskanen O, Lahti E, Jennings LC, Murdoch DR. Viral pneumonia. Lancet. 2011;377(9773):1264-75. http:// dx.doi.org/10.1016/S0140-6736(10)61459-6

5. Lanaspa M, Annamalay AA, Lesouef $P$, Bassat $Q$. Epidemiology, etiology, $x$-ray features, importance of co-infections and clinical features of viral pneumonia in developing countries. Expert review of anti-infective therapy. 2014;12(1):31-47. http://dx.doi.org/10.1586/147 87210.2014 .866517

6. World Health Organization. Global Influenza Surveillance and Response System (GISRS). 2014 [14 January 2014]; Available from: http://www.who.int/influenza/gisrs_ laboratory/en/

7. Joint United Nations Programme on HIV/AIDS. UNAIDS Report on the Global AIDS Epidemic 2010. 2010.

8. Scott JA, Hall AJ, Muyodi C, Lowe B, Ross M, Chohan B, et al. Aetiology, outcome, and risk factors for mortality among adults with acute pneumonia in Kenya. Lancet. 2000;355(9211):1225-30. http://dx.doi.org/10.1016/S01406736(00)02089-4

9. Tornheim JA, Manya AS, Oyando N, Kabaka S, Breiman RF, Feikin DR. The epidemiology of hospitalized pneumonia in rural Kenya: the potential of surveillance data in setting public health priorities. International Journal of Infectious Diseases. 2007;11(6):536-43. http://dx.doi.org/10.1016/j. 
ijid.2007.03.006

10. Vigil KJ, Adachi JA, Chemaly RF. Viral pneumonias in immunocompromised adult hosts. Journal of intensive care medicine. 2010;25(6):307-26. http://dx.doi. org/10.1177/0885066610377969

11. Bates M, Musonda K, Zumla A. Human Cytomegalovirus (HCMV) Infection in sub-Saharan Africa, Manifestations of Cytomegalovirus Infection: Winchester, Hampshire. Price PP, editor: InTechOpen; 2013:17-39

12. Cohen C, Moyes J, Tempia S, Groom M, Walaza S, Pretorius $M$, et al. Severe influenza-associated respiratory infection in high HIV prevalence setting, South Africa, 2009-2011. Emerging infectious diseases. 2013;19(11):1766-74. http:// dx.doi.org/10.3201/eid1911.130546

13. Monto AS. Seasonal influenza and vaccination coverage. Vaccine. 2010;28 Suppl 4:D33-44. http://dx.doi.org/10.1016/j. vaccine.2010.08.027

14. Centers for Disease Control and Prevention (CDC). Prevention and control of seasonal influenza with vaccines. Recommendations of the Advisory Committee on Immunization Practices, United States, 2013-2014. MMWR Recommendations and reports: Morbidity and mortality weekly report Recommendations and reports, Centers for Disease Control. 2013;62(RR-07):1-43

15. Duque J, McMorrow ML, Cohen AL. Influenza vaccines and influenza antiviral drugs in Africa: are they available and do guidelines for their use exist? BMC public health. 2014;14(1):41. http://dx.doi.org/10.1186/1471-2458-14-41

16. Jennings LC, Anderson TP, Beynon KA, Chua A, Laing RT, Werno AM, et al. Incidence and characteristics of viral community-acquired pneumonia in adults. Thorax. 2008;63(1):42-8. http://dx.doi.org/10.1136/ thx.2006.075077

17. Templeton KE, Scheltinga SA, van den Eeden WC, Graffelman AW, van den Broek PJ, Claas EC. Improved diagnosis of the etiology of community-acquired pneumonia with real-time polymerase chain reaction. Clinical Infectious Diseases. 2005;41(3):345-51. http://dx.doi.org/10.1086/431588

18. Johansson N, Kalin M, Tiveljung-Lindell A, Giske CG, Hedlund J. Etiology of community-acquired pneumonia: increased microbiological yield with new diagnostic methods. Clinical Infectious Diseases. 2010;50(2):202-9. http://dx.doi. org/10.1086/648678

19. Diederen BM, Van Der Eerden MM, Vlaspolder F, Boersma WG, Kluytmans JA, Peeters MF. Detection of respiratory viruses and Legionella spp. by real-time polymerase chain reaction in patients with community acquired pneumonia. Scandinavian journal of infectious diseases. 2009;41(1):4550. http://dx.doi.org/10.1080/00365540802448799

20. Saito A, Kohno S, Matsushima T, Watanabe A, Oizumi K, Yamaguchi $K$, et al. Prospective multicenter study of the causative organisms of community-acquired pneumonia in adults in Japan. Journal of Infection and Chemotherapy. 2006;12(2):63-9. http://dx.doi.org/10.1007/s10156-0050425-8

21. Lieberman $D$, Shimoni A, Shemer-Avni $Y$, Keren-Naos $A$, Shtainberg R, Lieberman D. Respiratory viruses in adults with community-acquired pneumonia. Chest. 2010;138(4):8116. http://dx.doi.org/10.1378/chest.09-2717

22. de Roux A, Ewig S, Garcia E, Marcos MA, Mensa J, Lode $\mathrm{H}$, et al. Mixed community-acquired pneumonia in hospitalised patients. The European Respiratory Journal. 2006;27(4):795-800. http://dx.doi.org/10.1183/09031936. 06.00058605
23. Charles PG, Whitby M, Fuller AJ, Stirling R, Wright AA, Korman TM, et al. The etiology of community-acquired pneumonia in Australia: why penicillin plus doxycycline or a macrolide is the most appropriate therapy. Clinical Infectious Diseases. 2008;46(10):1513-21. http://dx.doi. org/10.1086/586749

24. Johnstone J, Majumdar SR, Fox JD, Marrie TJ. Viral infection in adults hospitalized with community-acquired pneumonia: prevalence, pathogens, and presentation. Chest. 2008;134(6):1141-8. http://dx.doi.org/10.1378/ chest.08-0888

25. Angeles Marcos M, Camps M, Pumarola T, Antonio Martinez J, Martinez E, Mensa J, et al. The role of viruses in the aetiology of community-acquired pneumonia in adults. Antiviral therapy. 2006;11(3):351-9

26. Saito S, Howard AA, Reid MJ, Elul B, Scardigli A, Verkuijl $S$, et al. TB diagnostic capacity in sub-Saharan African HIV care settings. Journal of Acquired Immune Deficiency Syndromes. 2012;61(2):216-20. http://dx.doi.org/10.1097/ QAl.0b013e3182638ec7

27. Archer B, Cohen C, Naidoo D, Thomas J, Makunga C, Blumberg L, et al. Interim report on pandemic H1N1 influenza virus infections in South Africa, April to October 2009: epidemiology and factors associated with fatal cases. Euro surveillance, European communicable disease bulletin. 2009;14(42):1-5

28. Dalhatu IT, Medina-Marino A, Olsen SJ, Hwang I, Gubio $A B$, Ekanem EE, et al. Influenza viruses in Nigeria, 20092010: results from the first 17 months of a national influenza sentinel surveillance system. The Journal of infectious diseases. 2012;206 Suppl 1:S121-8. http://dx.doi. org/10.1093/infdis/jis584

29. Dia N, Ndiaye MN, Monteiro Mde L, Koivogui L, Bara MO, Diop OM. A subregional analysis of epidemiologic and genetic characteristics of influenza $A(H 1 N 1) p d m 09$ in Africa: Senegal, Cape Verde, Mauritania, and Guinea, 2009-2010. The American journal of tropical medicine and hygiene. 2013;88(5):946-53. http://dx.doi.org/10.4269/ ajtmh.12-0401

30. Lutwama JJ, Bakamutumaho B, Kayiwa JT, Chiiza R, Namagambo B, Katz MA, et al. Clinic- and hospital-based sentinel influenza surveillance, Uganda 2007-2010. The Journal of infectious diseases. 2012;206 Suppl 1:S87-93. http://dx.doi.org/10.1093/infdis/jis578

31. McAnerney JM, Cohen C, Moyes J, Besselaar TG, Buys A, Schoub BD, et al. Twenty-five years of outpatient influenza surveillance in South Africa, 1984-2008. The Journal of infectious diseases. 2012;206 Suppl 1:S153-8. http://dx.doi. org/10.1093/infdis/jis575

32. Muyembe Tamfum JJ, Nkwembe E, Bi Shamamba SK, Bankoshi F, llunga BK, Katz KA, et al. Sentinel surveillance for influenza-like illness, severe acute respiratory illness, and laboratory-confirmed influenza in Kinshasa, Democratic Republic of Congo, 2009-2011. The Journal of infectious diseases. 2012;206 Suppl 1:S36-40. http://dx.doi. org/10.1093/infdis/jis537

33. Niang $M N$, Dosseh A, Ndiaye K, Sagna M, Gregory V, Goudiaby $D$, et al. Sentinel surveillance for influenza in Senegal, 1996-2009. The Journal of infectious diseases. 2012;206 Suppl 1:S129-35. http://dx.doi.org/10.1093/ infdis/jis576

34. Njouom R, Mba SA, Noah DN, Gregory V, Collins P, Cappy P, et al. Circulation of human influenza viruses and emergence of Oseltamivir-resistant $\mathrm{A}(\mathrm{H} 1 \mathrm{~N} 1)$ viruses in Cameroon, 
Central Africa. BMC infectious diseases. 2010;10:56. http:// dx.doi.org/10.1186/1471-2334-10-56

35. Radin JM, Katz MA, Tempia S, Talla Nzussouo N, Davis R, Duque J, et al. Influenza surveillance in 15 countries in Africa, 2006-2010. The Journal of infectious diseases. 2012;206 Suppl 1:S14-21. http://dx.doi.org/10.1093/infdis/jis606

36. Rajatonirina S, Heraud JM, Orelle A, Randrianasolo L, Razanajatovo N, Rajaona YR, et al. The spread of influenza $A(H 1 N 1) p d m 09$ virus in Madagascar described by a sentinel surveillance network. PloS one. 2012;7(5):e37067. http:// dx.doi.org/10.1371/journal.pone.0037067

37. Theo A, Liwewe M, Ndumba I, Mupila Z, Tambatamba B, Mutemba $C$, et al. Influenza surveillance in Zambia, 20082009. The Journal of infectious diseases. 2012;206 Suppl 1:S173-7. http://dx.doi.org/10.1093/infdis/jis599

38. Mmbaga VM, Mwasekaga MJ, Mmbuji P, Matonya M, Mwafulango A, Moshi S, et al. Results from the first 30 months of national sentinel surveillance for influenza in Tanzania, 2008-2010. The Journal of infectious diseases. 2012;206 Suppl 1:S80-6. http://dx.doi.org/10.1093/infdis/ jis540

39. Feikin DR, Njenga MK, Bigogo G, Aura B, Aol G, Audi A, et al. Etiology and Incidence of viral and bacterial acute respiratory illness among older children and adults in rural western Kenya, 2007-2010. PloS one. 2012;7(8):e43656. http://dx.doi.org/10.1371/journal.pone.0043656

40. Katz MA, Lebo E, Emukule G, Njuguna HN, Aura B, Cosmas $L$, et al. Epidemiology, seasonality, and burden of influenza and influenza-like illness in urban and rural Kenya, 20072010. The Journal of infectious diseases. 2012;206 Suppl 1:S53-60. http://dx.doi.org/10.1093/infdis/jis530

41. Pretorius MA, Madhi SA, Cohen C, Naidoo D, Groome M, Moyes J, et al. Respiratory viral coinfections identified by a 10-plex real-time reverse-transcription polymerase chain reaction assay in patients hospitalized with severe acute respiratory illness--South Africa, 2009-2010. The Journal of infectious diseases. 2012;206 Suppl 1:S159-65. http:// dx.doi.org/10.1093/infdis/jis538

42. Bigogo GM, Breiman RF, Feikin DR, Audi AO, Aura B, Cosmas $L$, et al. Epidemiology of respiratory syncytial virus infection in rural and urban Kenya. The Journal of infectious diseases. 2013;208 Suppl 3:S207-16. http://dx.doi.org/10.1093/ infdis/jit489

43. 43. Steffen C, Debellut F, Gessner BD, Kasolo FC, Yahaya AA, Ayebazibwe $N$, et al. Improving influenza surveillance in subSaharan Africa. Bulletin of the World Health Organization. 2012;90(4):301-5

44. Joosting AC, Harwin RM, Orchard M, Martin E, Gear $\mathrm{JH}$. Respiratory viruses in hospital patients on the Witwatersrand. A 7-year study. South African Medical Journal. 1979;55(11):403-8

45. Hartung TK, Chimbayo D, van Oosterhout JJ, Chikaonda T, van Doornum GJ, Claas EC, et al. Etiology of suspected pneumonia in adults admitted to a high-dependency unit in Blantyre, Malawi. The American journal of tropical medicine and hygiene. 2011;85(1):105-12. http://dx.doi. org/10.4269/ajtmh.2011.10-0640

46. Feikin DR, Njenga MK, Bigogo G, Aura B, Aol G, Audi A, et al. Viral and bacterial causes of severe acute respiratory illness among children aged less than 5 years in a high malaria prevalence area of western Kenya, 2007-2010. The Pediatric infectious disease journal. 2013;32(1):e14-9. http://dx.doi. org/10.1097/INF.0b013e31826fd39b
47. Hohenthal U, Vainionpaa R, Meurman O, Vahtera A, Katiskalahti T, Nikoskelainen J, et al. Aetiological diagnosis of community acquired pneumonia: utility of rapid microbiological methods with respect to disease severity. Scandinavian journal of infectious diseases. 2008;40(2):1318. http://dx.doi.org/10.1080/00365540701534525

48. Levine OS, O'Brien KL, Deloria-Knoll M, Murdoch DR, Feikin DR, DeLuca AN, et al. The Pneumonia Etiology Research for Child Health Project: a 21st century childhood pneumonia etiology study. Clinical Infectious Diseases. 2012;54 Suppl 2:S93-101. http://dx.doi.org/10.1093/cid/cir1052

49. McCullers JA. Insights into the interaction between influenza virus and pneumococcus. Clinical microbiology reviews. 2006;19(3):571-82. http://dx.doi.org/10.1128/ CMR.00058-05

50. Brundage JF. Interactions between influenza and bacterial respiratory pathogens: implications for pandemic preparedness. The Lancet infectious diseases. 2006;6(5):30312. http://dx.doi.org/10.1016/S1473-3099(06)70466-2

51. Madhi SA, Klugman KP. A role for Streptococcus pneumoniae in virus-associated pneumonia. Nature medicine. 2004;10(8):811-3. http://dx.doi.org/10.1038/nm1077

52. Wolter N, Cohen C, Tempia S, Madhi SA, Venter M, Moyes $J$, et al. HIV and influenza virus infections are associated with increased blood pneumococcal load: a prospective, hospital-based observational study in South Africa, 20092011. The Journal of infectious diseases. 2014;209(1):5665. http://dx.doi.org/10.1093/infdis/jit427

53. Jartti $T$, Jartti L, Peltola V, Waris $M$, Ruuskanen $O$. Identification of respiratory viruses in asymptomatic subjects: asymptomatic respiratory viral infections. The Pediatric infectious disease journal. 2008;27(12):1103-7. http://dx.doi.org/10.1097/INF.0b013e31817e695d

54. Ison MG. Respiratory viral infections in transplant recipients. Antiviral therapy. 2007;12(4 Pt B):627-38

55. Jartti T, Lee WM, Pappas T, Evans M, Lemanske RF, Jr., Gern $J E$. Serial viral infections in infants with recurrent respiratory illnesses. The European Respiratory Journal. 2008;32(2):31420. http://dx.doi.org/10.1183/09031936.00161907

56. Brittain-Long R, Westin J, Olofsson S, Lindh $M$, Andersson LM. Prospective evaluation of a novel multiplex real-time PCR assay for detection of fifteen respiratory pathogensduration of symptoms significantly affects detection rate. Journal of Clinical Virology. 2010;47(3):263-7. http://dx.doi. org/10.1016/j.jcv.2009.12.010

57. Fry AM, Lu X, Olsen SJ, Chittaganpitch $M$, Sawatwong $P$, Chantra $S$, et al. Human rhinovirus infections in rural Thailand: epidemiological evidence for rhinovirus as both pathogen and bystander. PloS one. 2011;6(3):e17780. http://dx.doi.org/10.1371/journal.pone.0017780

58. Hicks LA, Shepard CW, Britz PH, Erdman DD, Fischer M, Flannery $\mathrm{BL}$, et al. Two outbreaks of severe respiratory disease in nursing homes associated with rhinovirus. Journal of the American Geriatrics Society. 2006;54(2):2849. http://dx.doi.org/10.1111/j.1532-5415.2005.00529.x

59. Wald TG, Shult P, Krause P, Miller BA, Drinka P, Gravenstein S. A rhinovirus outbreak among residents of a long-term care facility. Annals of internal medicine. 1995;123(8):588-93. http://dx.doi.org/10.7326/0003-4819-123-8-19951015000004

60. Echavarria M, Sanchez JL, Kolavic-Gray SA, Polyak CS, Mitchell-Raymundo F, Innis BL, et al. Rapid detection of adenovirus in throat swab specimens by PCR during 
respiratory disease outbreaks among military recruits. Journal of clinical microbiology. 2003;41(2):810-2. http:// dx.doi.org/10.1128/JCM.41.2.810-812.2003

61. Falsey AR, Criddle MC, Walsh EE. Detection of respiratory syncytial virus and human metapneumovirus by reverse transcription polymerase chain reaction in adults with and without respiratory illness. Journal of Clinical Virology. 2006;35(1):46-50. http://dx.doi.org/10.1016/j.jcv.2005.04.004

62. Cao B, Huang GH, Pu ZH, Qu JX, Yu XM, Zhu Z, et al. Emergence of community-acquired adenovirus type 55 as a cause of community-onset pneumonia. Chest. 2014;145(1):79-86. http://dx.doi.org/10.1378/chest.13-1186

63. Gunson RN, Collins TC, Carman WF. Real-time RT-PCR detection of 12 respiratory viral infections in four triplex reactions. Journal of Clinical Virology. 2005;33(4):341-4. http://dx.doi.org/10.1016/j.jcv.2004.11.025

64. Mahony JB. Nucleic acid amplification-based diagnosis of respiratory virus infections. Expert review of anti-infective therapy. 2010;8(11):1273-92. http://dx.doi.org/10.1586/ eri.10.121

65. Murdoch DR, Jennings LC, Bhat N, Anderson TP. Emerging advances in rapid diagnostics of respiratory infections. Infectious disease clinics of North America. 2010;24(3):791807. http://dx.doi.org/10.1016/j.idc.2010.04.006

66. Pillet $S$, Lardeux M, Dina J, Grattard F, Verhoeven P, Le Goff J, et al. Comparative evaluation of six commercialized multiplex PCR kits for the diagnosis of respiratory infections. PloS one. 2013;8(8):e72174. http://dx.doi.org/10.1371/ journal.pone.0072174

67. Murdoch DR, O'Brien KL, Scott JA, Karron RA, Bhat N, Driscoll AJ, et al. Breathing new life into pneumonia diagnostics. Journal of clinical microbiology. 2009;47(11):3405-8. http:// dx.doi.org/10.1128/JCM.01685-09

68. Karhu J, Ala-Kokko TI, Vuorinen T, Ohtonen P, Syrjala H. Lower Respiratory Tract Virus Findings in Mechanically Ventilated Patients With Severe Community-Acquired Pneumonia. Clinical Infectious Diseases. 2014

69. Jansen RR, Wieringa J, Koekkoek SM, Visser CE, Pajkrt D, Molenkamp R, et al. Frequent detection of respiratory viruses without symptoms: toward defining clinically relevant cutoff values. Journal of clinical microbiology. 2011;49(7):2631-6. http://dx.doi.org/10.1128/JCM.02094-10

70. Bosis S, Esposito S, Osterhaus AD, Tremolati E, Begliatti E, Tagliabue $C$, et al. Association between high nasopharyngeal viral load and disease severity in children with human metapneumovirus infection. Journal of Clinical Virology. 2008;42(3):286-90. http://dx.doi.org/10.1016/j. jcv.2008.03.029

71. Gerna G, Piralla A, Rovida F, Rognoni V, Marchi A, Locatelli F, et al. Correlation of rhinovirus load in the respiratory tract and clinical symptoms in hospitalized immunocompetent and immunocompromised patients. Journal of medical virology. 2009;81(8):1498-507. http://dx.doi.org/10.1002/ jmv. 21548

72. Schoub BD, Gessner BD, Ampofo W, Cohen AL, Steffen CA. Afriflu2--second international workshop on influenza vaccination in the African continent--8 November 2012, Cape Town (South Africa). Vaccine. 2013;31(35):3461-6. http://dx.doi.org/10.1016/j.vaccine.2013.04.021

73. Fields BS, House BL, Klena J, Waboci LW, Whistler T, Farnon EC. Role of global disease detection laboratories in investigations of acute respiratory illness. The Journal of infectious diseases. 2013;208 Suppl 3:S173-6. http://dx.doi. org/10.1093/infdis/jit490
74. Corbell C, Stergachis A, Ndowa F, Ndase P, Barnes L, Celum C. Genital ulcer disease treatment policies and access to acyclovir in eight sub-Saharan African countries. Sexually transmitted diseases. 2010;37(8):488-93

75. Centers for Disease Control and Prevention (CDC). Update: influenza activity - United States, 2009-2010 season. MMWR Morbidity and mortality weekly report. 2010;59(29):901-8

76. Fiore AE, Fry A, Shay D, Gubareva L, Bresee JS, Uyeki TM. Antiviral agents for the treatment and chemoprophylaxis of influenza, recommendations of the Advisory Committee on Immunization Practices (ACIP). MMWR Recommendations and reports: Morbidity and mortality weekly report, Recommendations and reports, Centers for Disease Control. 2011;60(1):1-24

77. Moscona A. Neuraminidase inhibitors for influenza. The New England journal of medicine. 2005;353(13):1363-73. http://dx.doi.org/10.1056/NEJMra050740

78. Jefferson $T$, Jones MA, Doshi P, Del Mar CB, Hama R, Thompson $\mathrm{MJ}$, et al. Neuraminidase inhibitors for preventing and treating influenza in healthy adults and children. The Cochrane database of systematic reviews. 2014;4:CD008965

79. Lee N, Chan PK, Hui DS, Rainer TH, Wong E, Choi KW, et al. Viral loads and duration of viral shedding in adult patients hospitalized with influenza. The Journal of infectious diseases. 2009;200(4):492-500. http://dx.doi. org $/ 10.1086 / 600383$

80. Lee N, Chan PK, Choi KW, Lui G, Wong B, Cockram CS, et al. Factors associated with early hospital discharge of adult influenza patients. Antiviral therapy. 2007;12(4):501-8.

81. Hanshaoworakul W, Simmerman JM, Narueponjirakul U, Sanasuttipun W, Shinde V, Kaewchana S, et al. Severe human influenza infections in Thailand: oseltamivir treatment and risk factors for fatal outcome. PloS one. 2009;4(6):e6051. http://dx.doi.org/10.1371/journal.pone.0006051

82. Lee N, Cockram CS, Chan PK, Hui DS, Choi KW, Sung JJ. Antiviral treatment for patients hospitalized with severe influenza infection may affect clinical outcomes. Clinical Infectious Diseases. 2008;46(8):1323-4. http://dx.doi. org/10.1086/533477

83. Lopez-Aldeguer J, Iribarren JA, Valencia E, Barquilla E, Knobel H, Santos J, et al. Outcomes in HIV-infected patients admitted due to pandemic influenza. Enfermedades infecciosas y microbiologia clinica. 2012;30(10):608-12. http://dx.doi.org/10.1016/j.eimc.2012.02.007

84. Aoki FY, Macleod MD, Paggiaro P, Carewicz O, El Sawy A, Wat C, et al. Early administration of oral oseltamivir increases the benefits of influenza treatment. The Journal of antimicrobial chemotherapy. 2003;51(1):123-9. http:// dx.doi.org/10.1093/jac/dkg007

85. Jefferson T, Del Mar CB, Dooley L, Ferroni E, Al-Ansary LA, Bawazeer GA, et al. Physical interventions to interrupt or reduce the spread of respiratory viruses. The Cochrane database of systematic reviews. 2011(7):CD006207.

86. Murni I, Duke T, Triasih R, Kinney S, Daley AJ, Soenarto $Y$. Prevention of nosocomial infections in developing countries, a systematic review. Paediatrics and International Child Health. 2013;33(2):61-78

87. Ntshoe GM, McAnerney JM, Tempia S, Blumberg L, Moyes $\mathrm{J}$, Buys $\mathrm{A}$, et al. Influenza Epidemiology and Vaccine Effectiveness among Patients with Influenza-Like Illness, Viral Watch Sentinel Sites, South Africa, 2005-2009. PloS one. 2014;9(4):e94681. http://dx.doi.org/10.1371/journal. pone.0094681 
88. Madhi SA, Maskew M, Koen A, Kuwanda L, Besselaar TG, Naidoo $D$, et al. Trivalent inactivated influenza vaccine in African adults infected with human immunodeficient virus: double blind, randomized clinical trial of efficacy, immunogenicity, and safety. Clinical Infectious Diseases. 2011;52(1):128-37. http://dx.doi.org/10.1093/cid/ciq004

89. Anema A, Mills E, Montaner J, Brownstein JS, Cooper C. Efficacy of influenza vaccination in HIV-positive patients: a systematic review and meta-analysis. HIV medicine. 2008;9(1):57-61. http://dx.doi.org/10.1111/j.1468-1293.2008.00515.x

90. Guvenel AK, Chiu C, Openshaw PJ. Current concepts and progress in RSV vaccine development. Expert review of

\section{vaccines. 2014}

91. Englund JA, Karron RA, Cunningham CK, Larussa P, Melvin $A$, Yogev R, et al. Safety and infectivity of two doses of live-attenuated recombinant cold-passaged human parainfluenza type 3 virus vaccine rHPIV3cp45 in HPIV3seronegative young children. Vaccine. 2013;31(48):570612. http://dx.doi.org/10.1016/j.vaccine.2013.09.046

92. Davis SM, Deloria-Knoll M, Kassa HT, O'Brien KL. Impact of pneumococcal conjugate vaccines on nasopharyngeal carriage and invasive disease among unvaccinated people: review of evidence on indirect effects. Vaccine. 2013;32(1):133-45. http://dx.doi.org/10.1016/j.vaccine.2013.05.005 